\title{
INTERDISCIPLINARY APPROACH TO TEACHING ENGLISH-LANGUAGE INTERACTION TO MULTINATIONAL STUDENTS WITHIN LEGAL DOMAIN
}

\author{
Tatiana V. Emelianova \\ Associate Professor, PhD (Pedagogy). Peoples' Friendship University of Russia (RUDN \\ University), the Institute of Law, 6, Miklykho-Maklaya Str., Moscow, 117198, Russian Federation, \\ emtv@mail.ru
}

\begin{abstract}
The purpose of this research is to study issues of interdisciplinary approach to teaching the Englishlanguage interaction to multinational non-immigrant masters of Arts within legal domain, to identify key communicative skills essential for lawyers' collaboration. This research uses a qualitative approach. The methodological basis is constituted by conceptual provisions of worldwide researchers of theory and methodology of teaching foreign languages, intercultural communication, competence approach, content and language integrated learning (CLIL), English for specific purposes (ESP), theoretical phonetics in linguistics. The novelty is in the interdisciplinary approach to teaching professionally-focused English-language intercultural interaction within legal domain to multinational non-immigrant masters of Arts at RUDN University which is based on three basics: received pronunciation (RP), legalese, and communicative competence formation. 179 texts at an intermediate level selected from numerous authentic resources reflecting law realities in Russia, the USA and UK were chosen; stress location factors in poly-stressed words were studied in the selected lexical corpus. Compiled by multinational non-immigrant students trilingual mini-vocabularies: triplets of polysyllabic English, Russian and their mother-tongue words (English Russian - Serbian/ Lezghian/ Kyrgyz, etc.) brought originality to this research. By the method of comparison and grouping, the study analysed a series of surveys of 50 masters of Arts aged 21-27 years to identify the resultativeness of the chosen interdisciplinary approach. This research practical value is in deepening multinational non-immigrant law-students' knowledge of the English and Russian languages through mastering their RP proficiency, writing and speaking skills of legal opinions' argumentation and justification, the norms of law competent elucidation. The results of the presented interdisciplinary approach can be applied by researchers of law and linguistics.
\end{abstract}

Keywords: interdisciplinary approach, legal domain, multinational non-immigrants, polysyllabic, trilingual.

\section{INTRODUCTION}

Integration of the discipline "Foreign Language" and professional (legal) data into non-linguistic Universities' language education processes prescribed new provisions for training achievement-oriented masters of Arts according to worldwide standards of professional criteria. The purpose of this research is to study issues of interdisciplinary method of teaching the English-language interaction to multinational non-immigrant masters of Arts within legal domain, to identify key communicative skills essential for lawyers' collaboration. This research uses a qualitative approach; research design is location, participants, context, author's role, validity. Qualitative research of teaching professionally-focused English-language intercultural interaction to nonimmigrant students of non-linguistic University is the applied instrument in selecting the interdisciplinary approach to the formation of masters of Arts' communicative competence, legalese skills, received pronunciation (RP) proficiency based on professional-context authentic audio-visuals and texts. These 
materials' authenticity is of crucial importance.

The methodological basis is constituted by conceptual provisions of worldwide researchers of theory and methodology of teaching foreign languages, intercultural communication, competence approach, content and language integrated learning (CLIL), English for specific purposes (ESP), theoretical phonetics in linguistics: Baradaran \& Alavi, (2015); Dudley-Evans \& St-John, (1998); Foote J.A. et.al. (2013); Howlader, (2010); Hismanoglu, M. \& Hismanoglu, S., (2010); Hutchinson \& Waters, (1996); Kennedy \& Bolitho, (1991); Ladefoged \& Maddieson, (1998); Richards, (2001); Simpson W.L.W. et.al., (2019); etc. The novelty is in the interdisciplinary approach to teaching professionally-focused English-language intercultural interaction within legal domain to multinational non-immigrant masters of Arts at RUDN University which is based on three basics: received pronunciation (RP), legalese, and communicative competence formation. 179 texts at an intermediate level selected from numerous authentic resources reflecting law realities in Russia, the USA and UK were chosen; stress location factors in poly-stressed words were studied in the selected lexical corpus. Compiled by multinational non-immigrant students trilingual mini-vocabularies: triplets of polysyllabic English, Russian and their mother-tongue words (for example: English - Russian - Mongolian/ Serbian/ Lezghian/ Kyrgyz, etc.) brought originality to this research. By the method of comparison and grouping, the study analysed a series of surveys of 50 masters of Arts aged 21-27 years to identify the resultativeness of the chosen interdisciplinary approach. The practical value of this research is in deepening multinational nonimmigrant law-students' knowledge of the English and Russian languages through mastering their writing and speaking skills including received pronunciation proficiency, legal opinions' argumentation and justification, the norms of law competent elucidation.

\section{METHODOLOGY}

RUDN University's multinational environment was the location of this research, 50 multinational nonimmigrant first-year master-students studying jurisprudence at Law Institute, RUDN University were the participants of this research. They were from CIS, Afghanistan, Iran, Mongolia, Peru, Serbia, Syria, Vietnam, etc. English and Russian were not their first language (L1) but the foreign languages, they experienced problems with polysyllabic words' correct accentuation throughout intercultural interaction.

These were the main criteria to select the participants, educational setting and context in which the research was conducted with this paper's author active participation in structuring and organising studying materials, managing and instructing the students, evaluating and controlling their results and achievements to explain and gloss over their mistakes. The criteria for validity and reliability in this research are masters of Arts' interdisciplinary results and achievements, RP, writing, speaking skills' development and implementation in professionally-focused English-language intercultural interaction.

Mastering students' writing and speaking skills compulsory for legal activities is one of fundamentals in training them for professionally-focused intercultural interaction, it comprises the possession of the content and form of the written/ spoken speech. Their minimum level of language acquisition must be B-1, they "can understand the main points of clear standard input on familiar matters regularly encountered in work... etc.., can produce simple connected text... Can describe experiences and events... and briefly give reasons and explanations for opinions and plans" according to Common European Framework of References for Languages (2002, p.24). The obligatory level for professional communication is even higher.

Having conducted the above qualitative analyses, to adequately evaluate this research results, throughout 2017-2020 at RUDN University 50 multinational non-immigrant first-year master-students were interviewed to find out their level of the English-language knowledge including RP proficiency in the legal context and their willingness to expand it. That was done additionally to grammatical-lexical entry tests for annual enrolment for masters' degree programmes in jurisprudence.

The data analysis revealed that $92 \%$ of respondents had problems with new polysyllabic words' pronunciation within legal domain, $8 \%$ had less worries using their background knowledge or intuition as they explained, but $100 \%$ consulted different dictionaries. English caused more worries than Russian for $100 \%$ of students due to their inexperience of professionally-focused English-language communication in legal domain; $100 \%$ of students' positive answers to questions 1, 2, 6 proved the actuality of the presented methodology. The answers' distribution is shown in Table 1. 
Table 1. Distribution of answers; the reviewed: 50 multinational non-immigrant first-year masters of

\begin{tabular}{|c|c|c|c|c|c|c|}
\hline \multicolumn{7}{|l|}{ rts } \\
\hline \multirow{4}{*}{ № } & \multirow[t]{4}{*}{ Questions } & \multirow{2}{*}{\multicolumn{2}{|c|}{\begin{tabular}{|c|}
$\begin{array}{c}\text { University } \\
\text { level, number } \\
\text { of respondents }\end{array}$ \\
Masters, 50 \\
\end{tabular}}} & \multicolumn{3}{|c|}{ Per cent } \\
\hline & & & & \multicolumn{3}{|c|}{$100 \%$} \\
\hline & & \multicolumn{5}{|c|}{ Answers } \\
\hline & & \begin{tabular}{|l|l|} 
M & Yes \\
& \\
\end{tabular} & Other & \begin{tabular}{l|}
$N$ \\
0
\end{tabular} & Yes & Other \\
\hline 1 & $\begin{array}{l}\text { Do you need to widen your knowledge and master writing and } \\
\text { speaking skills necessary for professionally-focused English- } \\
\text { language intercultural interaction? }\end{array}$ & 50 & & & 100 & \\
\hline 2 & $\begin{array}{l}\text { Do you think that for successful interaction in legal domain a } \\
\text { lawyer must be proficient in legal analysis and research, legal } \\
\text { documents and contracts drafting/ proofreading, disputes } \\
\text { regulation based on the acting legislation? }\end{array}$ & 50 & & & 100 & \\
\hline 3 & $\begin{array}{l}\text { Do you experience difficulties when you encounter an } \\
\text { unfamiliar polysyllabic word (4 or more syllables) within legal } \\
\text { domain? }\end{array}$ & 46 & 4 & & 92 & 8 \\
\hline 4 & $\begin{array}{l}\text { Does the English language usage cause more worries for you } \\
\text { than Russian during intercultural interaction? }\end{array}$ & 50 & & & 100 & \\
\hline 5 & $\begin{array}{l}\text { Do you overcome the difficulties with stress placement in } \\
\text { polysyllabic words using dictionaries? }\end{array}$ & 50 & & & 100 & \\
\hline 6 & $\begin{array}{l}\text { Do you want to advance your writing and speaking skills of the } \\
\text { legal opinions' argumentation and justification, the norms of } \\
\text { law competent elucidation both in the English and Russian } \\
\text { languages? }\end{array}$ & 50 & & & 100 & \\
\hline
\end{tabular}

This questionnaire revealed the necessity to develop writing/ speaking skills with special viewpoint of RP in interdisciplinary content. To achieve the above objectives, the proper structure of the studying course was outlined, the appropriate content was chosen: internet, digital sources, various resources of authentic texts, and compulsory specialised English-language literature with four coursebooks: "Legal English: How to Understand and Master the Language of Law" (McKay, Charlton, \& Barsoum, 2011), "Test your professional English: Law" (Brieger, 2002), "Professional English in use. Law" (Gillian \& Sally, 2009), "Introduction into International Legal English" (Krois-Linder, Firth, \& TransLegal $\left.\AA^{\circledR}, 2009\right)$. Then, the form and procedure for the results' assessment were determined and an appropriate fund of assessment tools was formed. The methodology of the experiment is a key point in this research; therefore, its processes' detailed description is presented below.

\section{RESULTS AND DISCUSSIONS}

The academic programmes and the curricula require implementation of various authentic resources; according to these demands, 179 texts at an intermediate level reflecting law reality in Russia, the USA and UK were chosen. Together with these texts' translation and analyses - content, grammar, stylistics, terminology, etc., stress location factors in poly-stressed words were studied in the selected lexical corpus. Compiled by multinational non-immigrant students trilingual mini-vocabularies: triplets of polysyllabic English, Russian and their mother-tongue words (English - Russian - Mongolian/ Lezghian/ Kyrgyz, etc.) brought originality to this research, for example:

Table 2. Triplets with the Lezghian language (one of the local rare languages in Dagestan, Russia)

\begin{tabular}{|c|c|c|c|}
\hline № & English & Russian & Lezghian \\
\hline 1 & Authenticate & Удостоверить & Тестикь авун \\
\hline 2 & Advocacy & Защита & Хуьдай кас \\
\hline 3 & Embezzlement & Хищение & Чуьнуьхун \\
\hline 4 & Juvenile & Несовершеннолетний & Балугъ туширн \\
\hline
\end{tabular}


Proceedings of INTCESS 2021 8th International Conference on Education and Education of Social Sciences 18-19 January, 2021

\begin{tabular}{|c|c|c|c|}
\hline 5 & Jurisprudence & Юриспруденция & Юридический кІвалахар \\
\hline 6 & Liability & Обязательство & Мажбурвал \\
\hline 7 & Responsibility & Ответственность & Жавабдарвал \\
\hline 8 & Resolution & Решение & Гъял авун \\
\hline 9 & Vengeance & Месть & Кьисас \\
\hline
\end{tabular}

By the method of comparison and grouping, the study analysed a series of surveys of 50 masters of Arts aged 21-27 years to identify the resultativeness of the chosen interdisciplinary approach. The next developed questionnaire was targeted to survey students' evaluation of their achievements in mastering RP, writing and speaking skills during English language acquisition in interdisciplinary context, thus, to distinguish this particular approach efficiency. For more objectivity, this survey was led after master programme's first year completion: students' very good grades for knowledge assessment tests were confirmed by perfect results of their self-evaluation presented via this survey in Table 3 . The results showed the adequacy of the chosen interdisciplinary approach. The data revealed that $100 \%$ of non-immigrants were interested in the selected authentic texts, audio-video materials; $100 \%$ of positive answers proved the efficacy of the developed language exercises, assignments targeted at RP practice, grammar and vocabulary revision. The students' triple sets of polysyllabic words including from their mother tongues proved the adequacy of the chosen methodology of mastering RP skills and increased their motivation level, that was proved by $100 \%$ of positive answers to question 3 . However, $96 \%$ of the reviewed students were sure they would benefit from the newly-learned vocabulary in future law practice, $4 \%$ chose "rather yes" answer being unaware if their future employment would require all the studied English-language vocabulary usage. It does not lessen the practical value of this research yet.

The survey verified that for $98 \%$ of non-immigrants the interactive part of the seminars, including open discussions, mock trials, projects, role-plays, etc. was sufficient for the development of professionallyfocused English-language speaking skills within legal context; the other $2 \%$ answered "rather yes" meaning to have more seminars than it was provided by the University curricula. This research success lies in the fact that $100 \%$ of all involved non-immigrants answered questions 6-8 positively: they succeeded in identifying the distinct features of professionally-focused English-language intercultural interaction including RP through the described above course of writing, speaking skills' training.

Table 3. Results of mastering writing and speaking skills including RP within the process of professionally-focused English-language acquisition in interdisciplinary context; respondents: 50 multinational masters of Arts of RUDN University

\begin{tabular}{|c|c|c|c|c|}
\hline \multirow{2}{*}{ Questions } & \multicolumn{3}{|c|}{ Answers } & \multirow{2}{*}{$\begin{array}{l}\text { Per } \\
\text { cent } \\
100 \\
\%\end{array}$} \\
\hline & $\begin{array}{l}Y \\
E \\
S\end{array}$ & $\begin{array}{l}\text { Rat } \\
\text { her } \\
\text { Yes }\end{array}$ & O & \\
\hline $\begin{array}{l}\text { 1. Are you satisfied with the choice, depth and coverage of legal } \\
\text { issues of the studied topics? }\end{array}$ & 50 & & & 100 \\
\hline $\begin{array}{l}\text { 2. Did the language exercises targeted at } R P \text { practice, grammar } \\
\text { and vocabulary revision help you to develop speaking and writing } \\
\text { skills? }\end{array}$ & 50 & & & 100 \\
\hline $\begin{array}{l}\text { 3. Did compiling trilingual mini-vocabularies (with the triple sets of } \\
\text { polysyllabic words using your mother tongue) help you in } \\
\text { mastering RP skills? }\end{array}$ & 50 & & & 100 \\
\hline $\begin{array}{l}\text { 4. Would you benefit from the newly-learned legal vocabulary in } \\
\text { future law practice? }\end{array}$ & 48 & 2 & & 96 \\
\hline $\begin{array}{l}\text { 5. Was the interactive part of the seminars, including open } \\
\text { discussions, debates, projects, role-plays, mock trials, etc. } \\
\text { sufficient for the development of professionally-focused English- } \\
\text { language speaking skills to be conversant within legal context? }\end{array}$ & 49 & 1 & & 98 \\
\hline $\begin{array}{l}\text { 6. Did all the interactive classroom activities help you to improve } \\
\text { your communication skills necessary for professionally-focused } \\
\text { English-language intercultural interaction within legal domain? }\end{array}$ & 50 & & & 100 \\
\hline $\begin{array}{l}\text { 7. Was it beneficial to use multiple software, Microsoft Teams, } \\
\text { Internet resources, online dictionaries and translator-programmes, } \\
\text { and other digital technologies throughout this studying process? }\end{array}$ & 50 & & & 100 \\
\hline $\begin{array}{l}\text { 8. Would you tell that your communication skills in oral and written } \\
\text { legal English were sufficiently developed through this programme } \\
\text { of professionally-focused language activities in connection with key } \\
\text { legal skills training including advocacy, court trials, interviewing } \\
\text { and advising, negotiation, legal writing and drafting, etc.? }\end{array}$ & 50 & & & 100 \\
\hline
\end{tabular}


The presented in histogram (Fig. 1) grading scale is based on the ECTS grading scale used at RUDN University. It is A-F, where A is the highest and E is the lowest grade to pass (A "excellent", B "very good", C "good", D "satisfactory", E "conditionally satisfactory"), FX "conditionally unsatisfactory" means that some additional work is required before credit can be awarded, F "unsatisfactory" (a failure). Thus, each year nonimmigrants entered at "C" level and completed the first year with "B" grade. This correlation of students' results to the entry level (initial assessment) within each of the research years demonstrates their proficiency progress marked by the line chart, thus, proving the implemented methodology relevance.

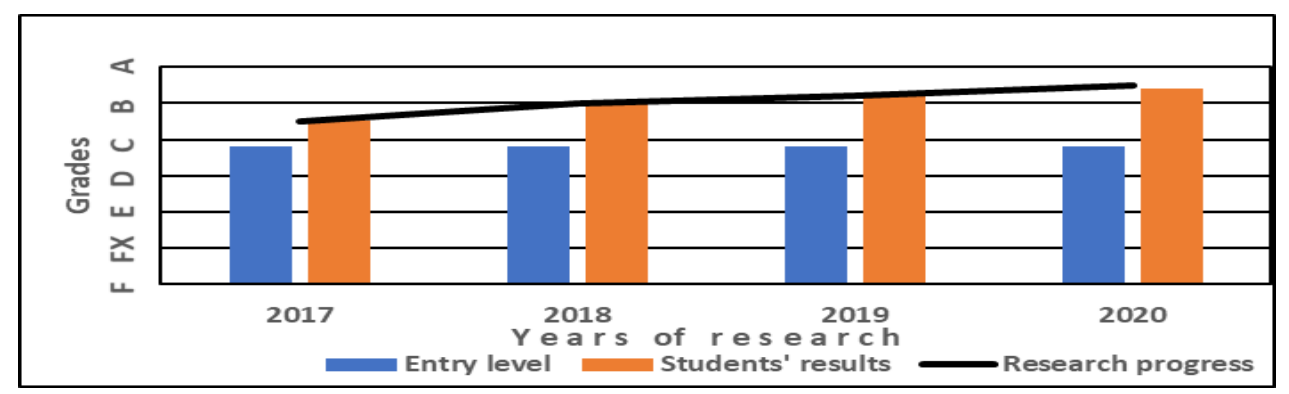

Fig. 1. The histogram is based on the ECTS grading scale $(A-F)$ with the line chart denoting research progress - correlation of students' results (red colour) to the entry level (initial assessment in blue colour) within research years

This study's strategic purposes were achieved, the interdisciplinary approach proved its efficacy. The achievements and progress of the involved students with approximately equal initial knowledge of RP and accentuation rules, writing, speaking skills in legal English showed the correctness of the chosen methodology of mastering their communicative skills necessary for legalese when studying professionallyfocused English in interdisciplinary context.

The result of all the above aspects' research can be formulated as follows:

1. The implemented interdisciplinary approach to training multinational non-immigrant Master of Arts' for professionally-focused English-language intercultural interaction proved its efficacy to develop their proficiencies in legal analysis, research, reasoning, interaction, legal documents and contracts drafting, proofreading, disputes regulation within communication processes based on the acting legislation; the applied methods of teaching like the IRAC analytical method, Socratic method, projects, case-studies, roleplays, mock trial, etc. were most appropriate and rewarding as a means of advantageous collaboration.

2. Mastering law-students' RP proficiency significantly contributed to their advance in professionally-focused English-language intercultural interaction with counterparts. Three factors - rhythmic (convenience of pronunciation), stylistic (sphere and frequency of use), and semantic that influence the accentuation of polysyllabic English/ Russian words were explained to masters of Arts during the above activities. This data usage helped them to compile the trilingual mini-vocabularies with triplets of polysyllabic English, Russian and their mother-tongue words thus extending their vocabulary which served as one of the key criteria of assessing their RP proficiency throughout this research process.

3. Masters of Arts' skills to adequately use law terminology in interpreting, translation and professionallyfocused English-language classroom activities were improved due to insight into the legal analysis basics as the result of personal and interdisciplinary achievements. Their involvement into classroom second-language acquisition advanced their writing, speaking skills of legal opinions' argumentation and justification, norms of law competent elucidation, thus, their knowledge of languages expanded in response to appropriate implementation of grammar, lexicology, morphology, phonetics, syntax, stylistics rules.

\section{IMPLICATION AND CONCLUSION}

Teaching ESP, CLIL focused on legal practice information gave the students an overall idea about legalese; this interdisciplinary course completion prepared them to successfully interact with intercultural counterparts. This study being based on the teacher's outlook on the benefits for non-immigrant students in non-linguistic university's intercultural environment, the predicted results of teaching in interdisciplinary context were achieved - the students' overall performance in the English-language professionally-focused interaction improved. Within the limits of this research, there were identified key communicative skills necessary for lawyers' intercultural collaboration: stress accentuation factors in polysyllabic English, Russian words and speaking, writing skills contributing to grammatical, lexical, phonetic, stylistic correctness of legalese, particularly, legal texts' composing: agreements, contracts, official letters, powers of attorneys, memorandum 
of association, settlements, plaints, procedural requests, numerous court documents, etc. Interactive teaching methods, modern educational technologies, audio visual aid, Internet resources implementation enhanced classroom learning activities efficacy to form students' socially significant competencies for professionally-focused English-language intercultural interaction. Involving the multinational students' mother tongues in compiling their mini vocabularies with the triple sets of poly-accented words was an unusual method, yet made delivering the curriculum material for international non-immigrant students more effective. Subsequently, eloquence and RP guarantee some influence in lawyers' professional communication.

The selected, carefully studied texts of professional content reflecting realities of law in Russia, UK and USA were helpful in the aforementioned context, they driven students to find new sources for widening their awareness of legalese with intention and motivation for future project work. The presented model of research is driven by continuous innovation; it can be motivating for the participation and involvement of other practitioners and educators into a wider research over the years. The provided tools, techniques and methodology may enable other researchers to reflect on a question or issue in their own context in a systematic way. The foremost innovations targeted to achieve the priority tasks to bridge the gap among the demands of education programmes, practice and employers were accomplished.

\section{REFERENCE LIST}

Baradaran, A., \& Alavi, M.R. (2015). The difference between extrovert/introversion EFL learners' cooperative writing. International Journal of Language and Learning and Applied Linguistics World (IJLIALW), 8, 13-24.

Brieger, N. (2002). Test your professional English: Law. Essex, England: Pearson Education Limited, Longman. P.112.

Common European Framework of Reference for Languages: Learning, teaching, assessment. (2002). Cambridge University Press. Cambridge, UK. pp. 1-265. Available at: https://rm.coe.int/1680459f97

Dudley-Evans, T., St-John, M.J. (1998). Developments in ESP. A multi-disciplinary approach. Cambridge, UK: Cambridge University Press. pp. 1-301.

Foote, J.A., Trofimovich, P., Collins, L. \& Fernanda Soler Urzúa. (2013). Pronunciation teaching practices in communicative second language classes 44 (2): 181-196 APR 2013. Available at: https://doi.org/10.1080/09571736.2013.784345

Gillian, D. B., \& Sally, R. (2009). Professional English in use. Law. Cambridge, UK: Cambridge University Press. P.128.

Howlader, M.R. (2010). Teaching English pronunciation in countries where English is a second language: Bangladesh perspective. ASA University Review, 4, 233-244.

Hismanoglu, M., \& Hismanoglu, S. (2010). Language teachers' preferences of pronunciation teaching techniques: Traditional or modern? Procedia Social and Behavioural Sciences, 2, 983-989. DOI: 10.1016/j.sbspro.2010.03.138

Hutchinson, T., Waters A. (1996). English for Specific Purposes. A learning-centred approach. England, UK: Cambridge University Press. pp. 1-183.

Kennedy, C., Bolitho, R. (1991). English for Specific Purposes. London, UK: Macmillan Press LTD. pp. 1149.

Krois-Linder, A., Firth, M., \& TransLegal®. (2009). Introduction into international legal English. Cambridge, UK: Cambridge University Press. P.160.

Ladefoged, P., Maddieson, I. (1998). The Sounds of the World's Languages. UK: Blackwell Publishing Ltd. P.430.

McKay, W.R., Charlton, H.E., Barsoum G. (2011). Legal English: How to Understand and Master the Language of Law. Pearson Education Ltd. P.256. ISBN 1408226111, 9781408226117

Richards, J.C. (2001). Curriculum Development in Language Teaching. Cambridge University Press. doi.org/10.1017/CBO9780511667220 